\title{
Deteksi Trichodina Sp Pada Budidaya Ikan Nila (Oreochormis Niloticus) Di Kecamatan Sayang - Sayang Kota Mataram
}

\section{Detection Of Trichodina Sp In Fish (Oreochormis Niloticus) Culture District Of Sayang- Sayang City Of Mataram}

\author{
Fahrisa Amalia Wardani ${ }^{(*)}$, Kunti Tirtasari ${ }^{2)}$, Candra Dwi Atma ${ }^{3)}$, Dina Oktaviana ${ }^{4)}$ \\ ${ }^{1)}$ Animal Health of Victory \\ ${ }^{2)}$ Dosen Divisi Kesehatan Masyarakat Veteriner, ${ }^{3)}$ Dosen Divisi Mikrobiologi dan \\ Parasitologi, ${ }^{4)}$ Dosen Divisi Produksi dan Reproduksi Veteriner \\ Fakultas Kedokteran Hewan, Universitas Pendidikan Mandalika \\ *Corresponding author : fahrisaamalia@gmail.com
}

\begin{abstract}
Abstrak
Ikan nila merupakan bahan pangan berprotein tinggi, murah, dan mudah dicerna oleh tubuh.Permasalahan yang banyak dialami oleh pembudidaya ikan nila adalah munculnya serangan penyakit.Tujuan penelitian ini adalah untuk mendeteksi adanya Trichodinia $s p$ pada ikan nila yang dibudidayakan di Kecamatan Sayang-sayang Kota Mataram.ini menggunakan rancangan desktiptif. Pengambilan sampel penelitian dilakukan menggunakan random sampling dari dua petak kolam.Sampel dari penelitian ini yaitu 6 sampel ikan nila, yang diambil secara acak dari pembudidaya di Pade Maju Kecamatan Sayang-sayang Kota Mataram.Hasil pemeriksaan menunjukkan 4 sampel terinfeksi Trichodina sp. Kesimpulan yang dapat diambil dari penelitian ini adalah parasit yang menginfeksi ikan nila (O. niloticus) yang ada di Kecamata Sayang-sayang Kota Mataram adalah Trichodina sp.
\end{abstract}

Kata kunci : Budidaya Ikan Sayang-sayang, Deteksi, Ikan nila, Trichodina sp

\begin{abstract}
Fish is a hight protein food, cheap and easily digested by the body. The problem that is experienced by many tilapia farmers is the emergence of desease. The purpose of this study was to detect the presence of Trichodina sp in tilapia which was cultivated in the District of Sayang - sayang City of Mataram. This use a descriptive design. Sampling was conducted using random sampling from two pond plots. Samples from this study were 6 saamples of tilapia, which were taken randomly from farmers in Pade Maju, District of Sayang - sayang City of Mataram. The results of the examination showed 4 samples were infected with Trichodina sp. the conclusion that can be drawn fromthis study is that parasites that infect tilapia (O. niloticus) in the District of Sayang - sayang City of Mataram are Trichodina sp.
\end{abstract}

Keywords: Aquaculture of Sayang - Sayang, Detection, Tilapia, Trichodina sp 


\section{Pendahuluan}

Subsektor perikanan memegang peranan penting dalam penyediaan protein hewani bagi masyarakat Indonesia. Produksi ikan mencapai kurang lebih 2 juta ton per tahun, sebagian besar $74 \%$ berasal dari laut dan sisanya 26\% dari air tawar (Mariyono dan Sundana, 2002). Ikan air tawar yang banyak disukai dan dibudidaya adalah ikan nila (Oreochromis niloticus) karena memiliki nilai ekonomi yang cukup tinggi dengan nilai gizi tidak kalah dibandingkan ikan yang lainnya (Martinus, 2013). Pertengahan tahun 2019 pembudidaya ikan di Kecamatan Sayangsayang mengalami kerugian yang cukup besar. Hal ini terjadi karena kematian ikan yang cukup banyak yang mengakibatkan menurunnya jumlah panen ikan budidaya di Kecamatan Sayang - sayang, salah satu penyebab kematian ini bisa terjadi karena adanya parasit.

Haryono, dkk (2016), telah melakukan penelitian pada ikan mas koki (Carrasius auratus) di Kecamatan CiseengKabupaten Bogor, didapatkan ikan di Kecamatan Ciseeng terinfeksi ektoparasit Trichodina sp. sebanyak 79\%. Penyakit akibat infeksi parasit merupakan ancaman yang cukup serius dibandingkan dengan gangguan dari faktor lain. Permasalahan yang banyak dialami oleh pembudidaya ikan nila adalah munculnya serangan penyakit. Penyakit yang dapat mengganggu proses pembudidayaan ikan nila salah satunya agen parasitik yaitu Trichodina sp. merupakan protozoa ektoparasit yang jika menginfeksi ikan nila dapat menyebabkan terjadinya luka pada sirip dan sisik ikan sehingga akan menyebabkan pertumbuhan ikan terhambat dan bisa menyebabkan kematian (Rustikawati $d k k$, 2004). Deteksi Trichodina $S p$ perlu dilakukan untuk mencegah terjadinya kerugian yang besar pada peternak, data deteksi dapat membantu peternak untuk melakukan langkah pencegahan sedini mungkin.

\section{Materi dan Metode}

Pengambilan sampel penelitian dilakukan menggunakan random sampling dari dua petak kolam.Sampel dinyatakan positif apabila ditemukan adanya ektoparasit Trichodina sp. Data yang diamati adalah deteksi keberadaan ektoparasit Trichodina sp.

Pembudidaya ikan di Kecamatan Sayang-sayang terdiri dari beberapa kelompok, salah satunya yaitu kelompok Pade Maju. Kelompok Pade Maju memiliki kolam sebanyak 2 petak dengan ukuran masing- masing $6 \times 3,5 \mathrm{~m}^{2}$ dan kedalaman mencapai $90 \mathrm{~cm}$. Jumlah populasi budidaya ikan nila disetiap petak kolam sebanyak 1.500 ekor ikan dengan sampel sebanyak 6 sampel ikan nila, kemudian dilakukan pemeriksaan dengan metode scraping. Rumus untuk menentukan jumlah sampel yaitu dengan menggunakan rumus Detect Of Deseases (Martin et al., 1987), dari hasil perhitungan diperoleh jumlah sampel sebanyak 3 sampel perpetak jadi total sampel sebanyak 6 ekor.

Trichodina Spdiambil dari tubuh ikan setelah dilakukan penyisikan. Pemeriksaan sampel ikan dilakukan di Laboratorium Equine Clinical Skills Center (CSC) Fakultas Kedokteran Hewan Universitas Pendidikan Mandalika.

Pemeriksaan dilakukan pada organ insang, dengan membuka pada bagian operculum ikan, insang ikan diambil serta disayat menjadi tipis lalu diletakkan di cawan petri, sehingga lembaran insang jelas kelihatan. Lembaran insang diambil, kemudian setiap lembar diletakkan di kaca objek ditetesi dengan aquades, selanjutnya dilihat di bawah lensa mikroskop perbesaran 400 x. Hasil. dapat dikatakan positif apabila terdapat Trichodina sp. Identifikasi Trichodina sp. dengan kunci indentifikasi menurut (Wellborn and Rogers 1970). Analisa data ini disajikan secara deskriptif dengan menampilkan data hasil pengamatan Trichodina spyang ditemukan. 


\section{Hasil dan Pembahasan}

Hasil identifikasi morfologi parasit tersebut menunjukkan bahwa parasit yang terdeteksi di ikan nila (O. niloticus) di
Kecamatan Sayang - sayang Kota Mataram adalah Trichodina sp setelah disamakan dengan kunci identifikasi menurut (Wellborn and Rogers 1970).

Gambar 1 Trichodina sp yang diperoleh dari scraping ingsang ikan

$\begin{array}{llrllll}\text { Berdasarkan hasil pemeriksaan } & 6 & \text { sampel ikan, ditemukan } & 4 & \text { sampel } \\ \text { Laboratorium yang telah dilakukan terhadap } & \text { terinfeksi Trichodina } \text { sp. }\end{array}$

Tabel 1 Hasil pemeriksaan laboratorium pada ikan nila (O. niloticus) di Kecamatan Sayang- sayang Kota Mataram

\begin{tabular}{c|c|c}
\hline Kode sampel & Positif & Negatif \\
\hline Ikan 1 & Positif & \\
\hline Ikan 2 & Positif & \\
\hline Ikan 3 & Positif & \\
\hline Ikan 4 & Positif & \\
\hline Ikan 5 & & Negatif \\
\hline Ikan 6 & & Negatif \\
\hline
\end{tabular}

Berdasarkan hasil penelitian yang dilakukan, parasit yang menginfeksi ikan nila (O. nilotucus) adalah Protozoa Trichodina sp. Pengambilan sampel yang dilakukan secara acak pada dua kolam yang ada, dapat dikatakan bahwa ikan nila yang rentan terkena Trichodina sp. merupakan ikan yang berumur kurang lebih empat bulan, hal ini disebabkan keadaan sistem imun dari ikan nila menurun akibat proses pemindahan ikan nila dari kolam yang lama ke kolam yang baru, Menurut Rustikawaty Dkk, (2004) yakni parasit Trichodinasp. paling banyak menginfeksi ikan berusia muda yang masih memiliki sistem imun yang rendah sehingga mudah terinfeksi oleh penyakit.

Faktor pendukung yang lain yakni tidak dibedakannya umur ikan dalam satu kolam dan tingkat kepadatan ikan yang cukup padat juga merupakan salah satu faktor pendukung. Hal ini juga berpeluang 
besar untuk berjangkitnya penyakit termasuk penyakit parasit dari satu individu ke individu ikan yang lainnya. Menurut Reiny (2011) bahwa kepadatan dan ruang gerak yang kecil akan terjadi persaingan dalam memperoleh makanan di wilayah pergerakan dari spesies yang dibudidayakan sehingga ikan mudah stress. Hal ini mempermudah ikan terinfeksi dan berpeluang terjadinya wabah. Menurut Mulia (2006), untuk tingkat padat penyebaran benih ikan pada kolam sebanyak $20 \mathrm{ekor} / \mathrm{m}^{2}$ atau $30 \mathrm{ekor} / \mathrm{m}^{2}$.

Faktor lainnya juga adalah air yang mengalir dari kolam langung berasal dari mata air atau aliran sungai yang mengalir.Proses pembudidaya di tempat penelitian memiliki sistem perairan air yang beasal dari sistem buka tutup (ketika air mencapai bibir kolam, maka air dihentikan masuk ke dalam kolam), kolam yang tenang tergenang dan tidak berarus memungkinkan infeksi Trichodina sp. lebih tinggi dibandingkan dengan kolam yang berarus deras (Nugraha, 2008). Hal ini juga dapat dipengaruhi oleh suhu air pada kolam, suhu optimal yakni $26-33^{\circ} \mathrm{C}$, bila suhu rendah ikan akan kehilangan nafsu makan sehingga pertumbuhan terhambat, sebaliknya bila suhu tinggi ikan akan stress bahkan mati kekurangan oksigen (Kordi, 2004). Tingkat keasaman $(\mathrm{pH})$, jika $\mathrm{pH}$ berkisar $5-6,5$ akan menyebabkan pertumbuhan ikan terhambat dan ikan menjadi sensitif terhadap bakteri dan parasit sedangkan untuk $\mathrm{pH}$ kurang dari 4,5 akan menyebabkan perairan beracun dan menyebabkan kematian pada ikan (Andri Kurniawan, 2016). Adanya penumpukan bahan organik seperti kotoran ikan serta penumpukan sisa - sisa pakan yang diberikan merupakan salah satu faktor pendukung ikan terinfeksi. (Pramono (2008) kualitas air pada kolam yang menurun dapat menyebabkan Trichodina sp. berkembang dengan cepat.

Faktor cuaca atau pergantian musim juga mempengaruhi proses reproduksi dari Trichodina sp. ini. Zainun (2008) dalam Mahatma, dkk (2012), menyatakan bahwa
Trichodina sp. merupakan ektoparasit yang menginfeksi kulit dan insang, biasanya menginfeksi semua jenis ikan air tawar. Populasi Trichodina sp. di air meningkat pada saat peralihan musim, dari musim panas ke musim dingin, sehingga kordi (2010) menyatakan bahwa pencegahan Trichodina sp. dengan mempertahankan kualitas air terutama stabilitas suhu air pada $29^{\circ} \mathrm{C}$, menjaga kebersihan kolam budidaya dan meningkatkan frekuensi pergantian air.

\section{Kesimpulan}

Berdasarkan penelitian ini dapat disimpulkan bahwa parasit yang menginfeksi ikan nila (O. niloticus) yang ada di Kecamata Sayang - sayang Kota Mataram adalah Trichodina sp.

\section{Ucapan Terima Kasih}

Terima kasih kepada semua pihak yang sudah membantu kelancaran penulisan artikel ilmiah ini

\section{Daftar Pustaka}

Afrianto dan Liviawaty. 1992. Pengendalian Hama dan Penyakit Ikan. Penerbit Kanisius, Yogyakarta.

Ali S.K.,Koniyo Y., dan Mulis.2013. Identifikasi Ektoparasit pada Ikan Nila (Oreochromis Niloticus) Di Danau Lomboto Provinsi Gorontalo.Fakultas Ilmu Pertanian Universitas Negeri Gorontalo.

Anshary, H. 2008. Tingkat Infeksi Parasit Pada Ikan Mas Koi (Cyprinus carpio) Pada Beberapa Lokasi Budidaya Ikan Hias di Makassar dan Gowa. Jaringan Sains dan Teknologi. Vol 8 No.2 hal 139-147

Budhiarta, S. 2002. Kapita Selekta Epidemiologi Veteriner. Bagian Kesehatan Masyarakat Veteriner. Fakultas Kedokteran Hewan. Universitas G7adjah Mada.Yogyakarta.

Cahyono, B. 2009. Budidaya Lele dan Betutu (Ikan Langka dan Bernilai) Pustaka Mina. Jakarta.

Durborrow, R.M. 2003. Protozoa Parasites. SRAC Publication No.4701. 
Fisheries and Aquaculture FAO, 1985. Training Manual Integratid Fish Farming in China. FAO.

Haryono S., Mulyana.,dan Lusiastuti M.A. 2016. Inventarisasi Ektoparasit pada Ikan Mas Koki Di Kecamatan Ciseeng- Kabuoaten Bogor.Fakultas Pertanian Universitas Djuanda Bogor.

Hassan, M.A.E.A, 1999. Trichodiniasis in Farmet Fres Water Tilapia in Eastern Saudi Arabia. Fisherier Research Center. Al- Qaatef. Saudi Arabia : 157-168.

Irianto, A. 2005. Patologi Ikan Teleostei. Gadja Mada University Press. Yogyakarta.

Jasmanindar, Y. 2011. Prevalensi Penyakit dan Ikan Air Tawar yang Dibudidayakan Di Kota/ Kabupaten Kupang.Perikanan dan Kelautan Fakultas Pertanian Universitas Nusa Cendana.

Kamelia M., Widiani N.,dan Adistyaningrum N. 2018. Analisis Perbedaan Jumlah Bakteri Pada Ikan Nila (Oreochromis Niloticus) Budidaya.

Klinger, R. and R.F. Flyod. 2013. Intoduction to Freshwater Fish Parasite. The Institude of Food and Agricultural Science (IFAS), University of Florida.

Kordi. M. G. H., 2004. Penganggulangan Hama dan Penyakit Ikan.Rineka Cipta dan Bina Adiaksara, Jakarta.

Kumalasari N. 2016. Pemeriksaan Ektoparasit Pada Ikan Lele Masamo (Calarias Gariepinus) Di Balai Pengembangan Teknologi Kelautan dan Perikanan, Sleman, Daerah Istimewa Yogyakarta.

Lestari A. 2011. Prevalensi Ektoparasit Protozoa Trichodina sp. pada Ikan Lele Dumbo (Clarias Gariepinus) Di Desa Ngabetan Kecamatan Cerme Kabupaten Gresik.Fakultas Kedokteran Hewan Universitas Airlangga Surabaya. Skripsi
Lukman, Mulyana,dan Mumpuni F.S., 2014. Efektivitas Pemberian Akar Tuba (Derris elliptica) Terhadap Lama Waktu Kematian Ikan Nila (Oreochromis niloticus). Fakultas Pertanian, Universitas Djuanda Bogor.

Martin SW, Meek A., and Willberg p. 1987.Veterinary

Epidemiologi.Ames lowa. Lowa state Universitas Presis.

Martinus H. 2013. Pengaruh Teknologi Terhadap Kesehatan Jakarta: Mitra Pertama Press.

Maryono dan S. Agus. 2002. Teknik pencegahan dan pengobatan penyakit bercak merah pada ikan air tawar yang disebabkan oleh bakteri Aeromonas hydrophylia Bull. Teknik Pertanian.

Mahatma. Radit, Yusfiati., Roza Elvira, dan Titrawati. 2012. Beberapa Aspek Biologi Ikan Bung ( Ciliata: Peritricia) Parasitic on Fishes "US Fish \& Wildlife Publication. Paper 105. The Jourrnal Of Parasitologi Vol. 50, No. 1, February 1964, p. 30- 35.

Mulia DS, 2006, Tingkat Infeksi Ektoparasit Protozoa Pada Benih Ikan Nila (Oreochormis niloticus) di Balai Benih Ikan (BBI) Pandak dan Sidabowa, Kabupaten Banyumas Fakultas Perikanan dan Ilmu Kelautan Universitas Muhammadiyah Purwokerto, Purwokerto [SKRIPSI].

Mulyani Y.S., Yullisman.,dan Fitrani M., 2014. Pertumbuhan dan Efisiensi Pakan Ikan Nila (Oreochromis Niloticus) yang dipuasakan secara Periodik. Fakultas Pertanian UNSRI.

Pramono, T. dan Syakuri, h. 2008. Infeksi Parasit Pada Permukaan Tubuh ikan Nilem ( Osteochilus hasellti) yang diperdagangkan di PPI Purbalingga. Ilmiah Perikanan. Vol.3 No.2 
Rahmi, 2012.Identifikasi Ektoparasit pada Ikan Nila (Oreochromis Niloticus) Yang Dibudidayakan Pada Tambak Kabupaten Maros.Fakultas Pertania Universitas Muhammadiyah Makassar.

Rambe N., Yusni E., 2017. Prevalensi Ektoparasit Pada Benih Ikan Nila (Oreochromis Niloticus) pada Kolam Budidaya Di Desa Baru ladang Bambu Kecamatan Medan Tuntungan. Fakultas Pertanian Universitas Sumatera Utara.

Rustikawati, R. 1997. Budidaya dan Prospek Agribisnis. Kanisius, Yogyakarta.

Salsabila M., Suprapto H., 2015. Teknik Pembesaran Ikan Nila (Oreochromis Niloticus) Di Instalasai Budidaya Air Tawar Pandaan Jawa Timur.Fakultas Perikanan dan Kelautan Universitas Airlangga Surabaya.

Saanin H. 1984. Taksonomi dan Kunci Identifikasi Ikan. Jakarta: Bina Cipta.

Santoso, B, dan T.S. Wikatma. 2001. Petunjuk Praktis Budidaya Nila. Yogyakarta: penerbit kanisius.

Sarjito., Prayitno S.B., dan Harditomo A.H.C., 2013. Buku Pengantar Parasit Dan Penyakit Ikan.
Fakultas Perikanan dan Ilmu Kelautan Universitas Diponegoro.

Sugiarto. 1988. Teknik Pembenihan Ikan Mujair dan Nila. CV Simplex. Jakarta.

Sumantadinata, K. 1983. Pengembangan Ikan Ikan Peliharaan di Indonesia. Jakarta. Sastra Hudaya.

Thrusfield, M. 2015. Veterinary Epidemiologi. $2^{\text {nd }}$

Edition.Blackwell Science Oxford.117-198.

Welborn Thomas L. Jr. and Rogers Wilmer A. 1970. A Key To The Common Parasitic Protozoans Of North American Fishes.

Winaruddin.,Rusli.,Razi K., 2015. Infestasi Ektoparasit Pada Ikan Lele Dumbo (Clarias Gariepinus) Yang Dibudidaya Di Desa Tumpok Teungoh kecamatan Banda Sakti Kota Lhokseumawe. Fakultas Kedokteran Hewan Universitas Syiah Kuala Banda Aceh.

Yuli S., Haris H., Yusanti I.A., 2017. Tingkat serangan Ektoparasit pada Ikan Patin (pangasius hypopthalmus) yang Dibudidayakan dalam Keramba Jaring Apung Di Sungai Musi Palembang.Fakultas Perikanan Universitas PGRI Palembang. 